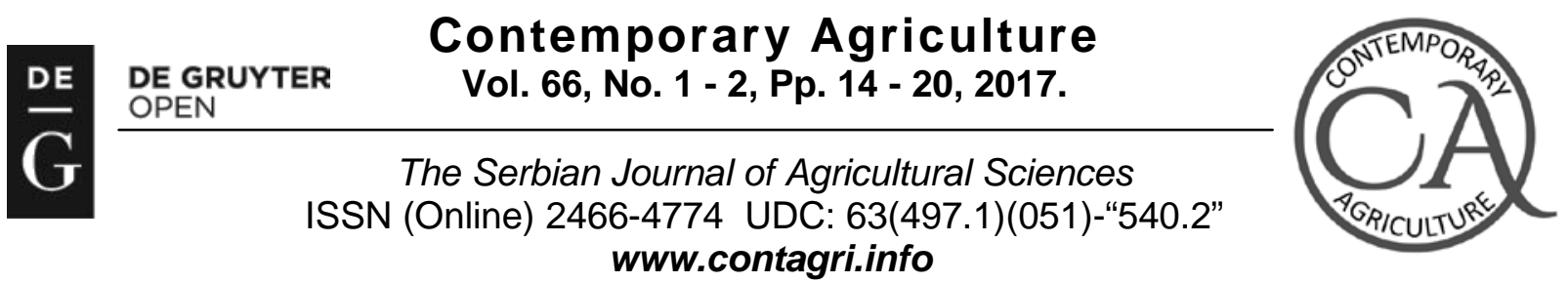

Original scientific paper

UDC: 551.577 .38 .582 .736 .3

DOI: $10.1515 /$ contagri-2017-0003

\title{
IMPACT OF DEFICIT IRRIGATION ON YIELD AND CHEMICAL PROPERTIES OF SOYBEAN SEEDS IN TEMPERATE CLIMATE
}

\author{
Branka KRESOVIĆ ${ }^{1}$, Boško GAJIĆ ${ }^{2 \star}$, Angelina TAPANAROVA², Borivoj PEJIĆ ${ }^{3}$, Goran \\ DUGALIĆC $\dot{C}^{4}$ Zorica SREDOJEVIĆ
}

\begin{abstract}
Summary: The goal of this research is to determine the effects of different levels of water deficit ( $I_{100}$ : full irrigation, $I_{65}$ : $35 \%$ deficit, $I_{40}$ : $60 \%$ deficit and $I_{0}$ : no irrigation) on yield and chemical composition of soybean [Glycine max (L.) Merr.] grown in Srem region of Serbia. Water deficit significantly affected the yield and chemical composition of soybean seeds. The lowest (1.63 t/ha) and the highest (3.21 t/ha) seed yields were obtained from $I_{0}$ and $I_{65}$ treatments, respectively. Furthermore, the highest protein $(1092 \mathrm{~kg} / \mathrm{ha})$ and oil $(563 \mathrm{~kg} / \mathrm{ha})$ yields were observed in $I_{65}$ treatment. Lower and higher irrigation levels from $I_{65}$ decreased the protein and oil yields. Our data indicated that irrigation generally increased $K, P, M g, M n, C u, Z n$ and $B$ concentrations and decreased Ca and Fe concentrations in soybean seed. It was clearly observed that full-watered treatment ( $\left.I_{100}\right)$ provided no potential benefit in terms of soybean yield and chemical composition. For higher economic yield and good nutritional quality, water-saving treatment $I_{65}$ could be suitable in soybean management in Srem region of Serbia as in other regions with similar soil and climate conditions.
\end{abstract}

Key words: soybean, drought stress, nutrient, protein and oil yield, mineral content

\section{INTRODUCTION}

In view of its unique chemical composition, soybean [Glycine max (L.) Merr.] is one of the most important crops worldwide. People have been consuming soybean for thousands of years and many newly-developed products are based on soybeans (Liu, 1997). Soybean is grown in Serbia on about 159,000 ha; annual yields range from 1.7 to 3.5 $\mathrm{t} \mathrm{ha}^{-1}$, or are $2.5 \mathrm{t} \mathrm{ha}^{-1}$ on average (Statistical Yearbook of the Republic of Serbia, 2015). The total annual output of 399,000 tons is not sufficient to meet the national demand. In Serbia soybean is mostly rainfed. Low and variable yields are generally caused by low precipitation levels and uneven distribution during the growing season.

Compared to other crops, soybean requires a lot of water for good quality and high yields (Sweeney et al., 2003). Still, soybean is largely rainfed in regions where there is propensity for drought (Kim et al., 2007). Water stress during the growing season is harmful to soybean development (Karam et al., 2005) and significantly reduces yields if it occurs in the flowering and podding stages because the flowers and pods are shed (Liu et al. 2003). Soybean yield and quality are sensitive to irrigation (Liu et al., 2004). However, there is a significant spatial and temporal variability of rainfed and irrigated soybean yields, which can be attributed to the soil, agrotechnical measures or their interactions. Knowledge of the chemical composition of soybean is expected to help determine how irrigation affects its nutritional value. No information is available on the effect of different irrigation levels on soybean yield and quality in the ecological conditions in Srem. Thus, the aim of this study was to evaluate the effects of different irrigation deficits on the yield and chemical composition of soybean grown on a silty loam soil in a temperate environment.

\footnotetext{
${ }^{1}$ Branka Kresović, PhD, Senior Research Associate, Maize Research Institute "Zemun Polje”, Slobodana Bajića 1, 11185 Belgrade, Serbia;

${ }^{2}$ Boško Gajić, PhD, Full Professor, Angelina Tapanarova, PhD, Senior expert associate, Zorica Sredojević, Full Professor, University of Belgrade, Faculty of Agriculture, Nemanjina 6, 11080 Belgrade, Serbia;

${ }^{3}$ Borivoj Pejić, PhD, Associated Professor, University of Novi Sad, Faculty of Agriculture, Sq. Dositej Obradović 8, 21000 Novi Sad, Serbia;

${ }^{4}$ Goran Dugalić, PhD, Full Professor, University of Kragujevac, Faculty of Agronomy Čačak, Cara Dušana 34, 32000 Čačak, Serbia.

•Corresponding author: e-mail: bonna@agrif.bg.ac.rs, Tel: +381 114413138.
} 


\section{MARERIALS AND METHODS}

Experimental site and climate. The field experiment was carried out during the 2015 growing season at the irrigated experimental field of the Maize Research Institute of Zemun Polje in Belgrade, Serbia (4452' N; 20²0' E), on silty clay soil. The physical and chemical properties of the soil are favorable and there is no waterlogging. In the experimental year 2015 , the average temperatures $\left(19.5^{\circ} \mathrm{C}\right)$ in the growing season (April-September) were higher than the average long-term temperature of $18.6^{\circ} \mathrm{C}$ (data not shown). Total rainfall during the soybean growing season was $~ 280 \mathrm{~mm}$ in 2015, which was significantly lower than the long-term average rainfall of $384 \mathrm{~mm}$.

Experimental setup. The soybean variety Nena (maturity group II), selected at the Maize Research Institute of Zemun Polje, was tested. The treatments were four irrigation levels: full irrigation - no water stress $\left(\mathrm{I}_{100}\right), \mathrm{I}_{65}-65 \%$ of $\mathrm{I}_{100}$ ( $35 \%$ water deficit - minimal to moderate stress), $\mathrm{I}_{40}-40 \%$ of $\mathrm{I}_{100}(60 \%$ water deficit - high water stress), and no irrigation $\left(\mathrm{I}_{0}\right)$ - rainfed conditions. The treatments were replicated four times in a completely randomized design. Individual experimental plots were comprised of 16 rows, $7.14 \mathrm{~m}$ long. Inter-row distance was $0.5 \mathrm{~m}$ and sowing density was 44.5 seeds per $\mathrm{m}^{2}$. Soil cultivation and application of fertilizers and herbicides were the same for all treatments. All plots were irrigated by a hand-move sprinkler system. Irrigation was initiated when the soil moisture in treatment $\mathrm{I}_{100}$ in the crop root zone was roughly $50 \%$ of the accessible water. Amounts of irrigation water applied to $\mathrm{I}_{100}, \mathrm{I}_{65}, \mathrm{I}_{40}$ and $\mathrm{I}_{0}$ treatments during the soybean growing period were 235,153 , 94, and $0 \mathrm{~mm}$, respectively. The yield of each plot was determined by manual counting in two central consecutive rows, $5 \mathrm{~m}$ long (the harvested surface area was $5 \mathrm{~m}^{2}$ ), and adjusted to a moisture content of $130 \mathrm{~g} / \mathrm{kg}$.

Chemical analysis. The content of protein and oil and the mineral composition were determined after harvesting and drying at $60^{\circ} \mathrm{C}$ until no moisture was left. The soybean was then ground by means of a laboratory grinder, Cyclotec 1093 (FOSS Tecator, Sweden). The protein and oil contents were determined by near-infrared (NIR) spectroscopy (Instalab 700 NIR Grain Analyzer, DICKEY-john, USA). The protein and oil yields (kg/ha) were calculated by multiplying the seed yield by the protein/oil content. Calcium (Ca), magnesium (Mg), iron (Fe), manganese $(\mathrm{Mn})$, copper $(\mathrm{Cu})$ and zinc $(\mathrm{Zn})$ concentrations were determined by atomic absorption spectrometry (Varian Spectra AA 220). Phosphorus (P) was determined by colorimetry and potassium (K) by flame photometry. Samples were assayed in triplicate.

Statistical analysis. All the experimental data were subjected to ANOVA using SPSS software (V 20). The significant differences between the treatments $(P \leq 0.05)$ were separated by a LSD test. SPSS (V20) was used to determine the correlation coefficient. The correlation between the treatments and protein yield and oil yield was determined by regression analysis.

\section{RESULTS}

Seed yield. As expected, non-irrigated treatment $\left(\mathrm{I}_{0}\right)$ resulted in significantly lower $(P<0.05)$ seed yields compared to irrigated treatments (Table 1). Seed yield ranged from $1.63 \mathrm{t} / \mathrm{ha}$ in rainfed $\left(\mathrm{I}_{0}\right)$ treatment to $3.21 \mathrm{t} / \mathrm{ha}$ in fully irrigated treatment. The yield under treatment $\mathrm{I}_{65}$ was significantly higher than the yield under the other two irrigation treatments (3.21 vs. 2.69 and $2.55 \mathrm{t} / \mathrm{ha}$, respectively for $\mathrm{I}_{100}$ and $\mathrm{I}_{40}$ ).

Table 1. Effects of different irrigation regimes on yield and selected nutritional compositions (such as protein, oil, $\mathrm{P}, \mathrm{K}, \mathrm{Ca}, \mathrm{Mg}$, Fe, $\mathrm{Mn}, \mathrm{Cu}, \mathrm{Zn}$ ) in soybean seeds

\begin{tabular}{|c|c|c|c|c|c|c|c|c|c|c|c|c|c|}
\hline & $\mathbf{S Y}$ & $\mathbf{P C}$ & $\mathbf{P Y}$ & $\mathbf{O C}$ & $\mathbf{O Y}$ & $\mathbf{P}$ & $\mathbf{K}$ & $\mathbf{C a}$ & $\mathbf{M g}$ & $\mathbf{F e}$ & $\mathbf{M n}$ & $\mathbf{C u}$ & $\mathbf{Z n}$ \\
\hline $\mathbf{I T}^{\mathbf{a}}$ & $\mathbf{t} / \mathbf{h a}$ & $\mathbf{\%}$ & $\mathbf{k g} / \mathbf{h a}$ & $\mathbf{\%}$ & $\mathbf{k g} / \mathbf{h a}$ & $\mathbf{\%}$ & $\mathbf{\%}$ & $\mathbf{\%}$ & $\mathbf{\%}$ & $\mathbf{m g} / \mathbf{k g}$ & $\mathbf{m g} / \mathbf{k g}$ & $\mathbf{m g} / \mathbf{k g}$ & $\mathbf{~ m g} / \mathbf{k g}$ \\
\hline $\mathrm{I}_{0}$ & $1.63 \mathrm{~d}$ & $37.0 \mathrm{~b}$ & $526 \mathrm{~d}$ & $20.1 \mathrm{a}$ & $285 \mathrm{~d}$ & $0.93 \mathrm{~d}$ & $1.65 \mathrm{~d}$ & $0.29 \mathrm{a}$ & $0.18 \mathrm{~d}$ & $64.5 \mathrm{a}$ & $33.8 \mathrm{~b}$ & $11.5 \mathrm{c}$ & $36.6 \mathrm{~b}$ \\
\hline $\mathrm{I}_{40}$ & $2.55 \mathrm{c}$ & $37.1 \mathrm{~b}$ & $822 \mathrm{c}$ & $20.0 \mathrm{a}$ & $450 \mathrm{c}$ & $0.97 \mathrm{c}$ & $1.72 \mathrm{a}$ & $0.26 \mathrm{c}$ & $0.21 \mathrm{c}$ & $59.9 \mathrm{c}$ & $34.1 \mathrm{~b}$ & $14.3 \mathrm{~b}$ & $36.2 \mathrm{~b}$ \\
\hline $\mathrm{I}_{65}$ & $3.21 \mathrm{a}$ & $39.2 \mathrm{a}$ & $1092 \mathrm{a}$ & $20.2 \mathrm{a}$ & $563 \mathrm{a}$ & $0.99 \mathrm{a}$ & $1.70 \mathrm{c}$ & $0.27 \mathrm{~b}$ & $0.23 \mathrm{a}$ & $61.4 \mathrm{~b}$ & $38.4 \mathrm{a}$ & $15.1 \mathrm{a}$ & $37.0 \mathrm{a}$ \\
\hline $\mathrm{I}_{100}$ & $2.69 \mathrm{~b}$ & $36.5 \mathrm{c}$ & $853 \mathrm{~b}$ & $20.3 \mathrm{a}$ & $471 \mathrm{~b}$ & $0.98 \mathrm{~b}$ & $1.71 \mathrm{~b}$ & $0.24 \mathrm{~d}$ & $0.22 \mathrm{~b}$ & $61.7 \mathrm{~b}$ & $38.8 \mathrm{a}$ & $15.1 \mathrm{a}$ & $36.6 \mathrm{~b}$ \\
\hline Mean & 2.52 & 37.5 & 823 & 20.1 & 442 & 0.97 & 1.69 & 0.26 & 0.21 & 61.9 & 36.3 & 14.0 & 36.6 \\
\hline $\mathbf{C V ( \% )}$ & $\mathbf{3 . 4 9}$ & $\mathbf{1 . 5 8}$ & $\mathbf{4 . 2 9}$ & $\mathbf{1 . 1 8}$ & $\mathbf{3 . 6 8}$ & $\mathbf{0 . 6 9}$ & $\mathbf{0 . 2 9}$ & $\mathbf{7 . 1 7}$ & $\mathbf{1 . 5 9}$ & $\mathbf{1 . 4 5}$ & $\mathbf{1 . 9 3}$ & $\mathbf{1 . 5 2}$ & $\mathbf{0 . 6 4}$ \\
\hline
\end{tabular}

${ }^{\mathrm{a}} \mathrm{IT}=$ Irrigation treatments, $\mathrm{SY}=$ seed yield, $\mathrm{PC}=$ protein content, $\mathrm{PY}=$ protein yield, $\mathrm{OC}=$ oil content, $\mathrm{OY}=$ oil yield, $\mathrm{CV}=$ coefficient of variation (\%).

${ }^{\mathrm{b}}$ Means followed by the same letter in the column are not significantly different at the $P=0.05$ level. 
Protein and oil content. The average protein and oil content of soybean, as well as the protein and oil yields, are shown in Table 1. Irrigation treatment $\mathrm{I}_{65}$, which achieved the highest seed yields, had the highest protein content, $39.2 \%$, followed by $\mathrm{I}_{40}, \mathrm{I}_{0}$ and $\mathrm{I}_{100}$ irrigation treatments with $37.1 \%, 37.0 \%$ and $36.5 \%$, respectively. In our study, there was no statistically significant difference in protein content between the rainfed treatment $\left(\mathrm{I}_{0}\right)$ and $\mathrm{I}_{40}$.

The calculated irrigated soybean protein yields ranged from 822 to $1092 \mathrm{~kg} / \mathrm{ha}$, and rainfed was $526 \mathrm{~kg} / \mathrm{ha}$. Treatment $\mathrm{I}_{65}$ recorded the highest protein yields. On average, irrigation treatments $\mathrm{I}_{100}, \mathrm{I}_{65}$ and $\mathrm{I}_{40}$ resulted in 62, 108 and $56 \%$ higher protein yields per hectare, respectively, compared to $\mathrm{I}_{0}$. The correlation between the protein yield and the amount of irrigation water is shown in Figure 1.

The results of this research indicate that there were no significant differences in the oil content between $\mathrm{I}_{100}, \mathrm{I}_{65}$, $\mathrm{I}_{40}$ and $\mathrm{I}_{0}$ treatments. The average oil content, regardless of treatment, varied over a very narrow interval, from 20.0 to $20.3 \%$. On average, fully irrigated treatments $\mathrm{I}_{100}$ registered the highest oil content and followed the series $\mathrm{I}_{100}>$ $\mathrm{I}_{65}>\mathrm{I}_{0}>\mathrm{I}_{40}$.

Contrary to the oil content, irrigation resulted in a significant increase in oil yields per hectare, due to different seed yields. In the present research, the highest average oil yield was achieved under treatment $I_{65}(563 \mathrm{~kg} / \mathrm{ha})$, followed by $\mathrm{I}_{100}(471 \mathrm{~kg} / \mathrm{ha})$ and $\mathrm{I}_{40}(450 \mathrm{~kg} / \mathrm{ha})$. Rainfed $\left(\mathrm{I}_{0}\right)$ soybean had the lowest average oil yield ( $\left.285 \mathrm{~kg} / \mathrm{ha}\right)$. Percent-wise, the rainfed treatment $\left(\mathrm{I}_{0}\right)$ registered 39, 49 and 37\% lower oil yields per hectare, on average, than irrigation treatments $\mathrm{I}_{100}, \mathrm{I}_{65}$ and $\mathrm{I}_{40}$, respectively. The correlation between the oil yield and the amount of irrigation water is shown in Figure 1.

Mineral composition. The concentrations of macrominerals in soybean seed are shown in Table 1. These results show that the irrigation had a significant $(P<0.05)$ effect on the concentrations of $\mathrm{P}, \mathrm{K}, \mathrm{Ca}$ and $\mathrm{Mg}$. Among the analyzed macrominerals, the highest concentration was that of $\mathrm{K}$, followed by $\mathrm{P}$, Ca, and Mg. Irrigation treatment $\mathrm{I}_{65}$ had the highest $\mathrm{P}$ and $\mathrm{Mg}$ concentrations and treatment $\mathrm{I}_{40}$ the highest concentration of $\mathrm{K}$. Ca concentration in treatment $\mathrm{I}_{0}$ was much higher than in irrigation treatments.

The irrigation levels also had a major impact on the concentrations of microminerals (Table 1). Reported results show that there has been no distinct relationship between micromineral concentrations and the studied irrigation treatments. In the current experiment, irrigation regimes significantly $(P<0.05)$ decreased Fe concentrations. There was no significant $(P<0.05)$ difference in Fe concentrations between $\mathrm{I}_{65}$ and $\mathrm{I}_{100}$ treatments. Non-irrigated treatment and deficit-irrigated treatment $\mathrm{I}_{40}$ resulted in lower $\mathrm{Cu}$ and $\mathrm{Mn}$ concentrations than $\mathrm{I}_{65}$ and $\mathrm{I}_{100}$ treatments.

There was no statistically significant $(P<0.05)$ difference in Mn concentration between $\mathrm{I}_{0}$ and $\mathrm{I}_{40}$ treatments and between $\mathrm{I}_{65}$ and $\mathrm{I}_{100}$ treatments. As seen in Table 1, there were no large differences in Mn and Cu concentrations between fully irrigated $\left(\mathrm{I}_{100}\right)$ and $\mathrm{I}_{65}$ treatments.

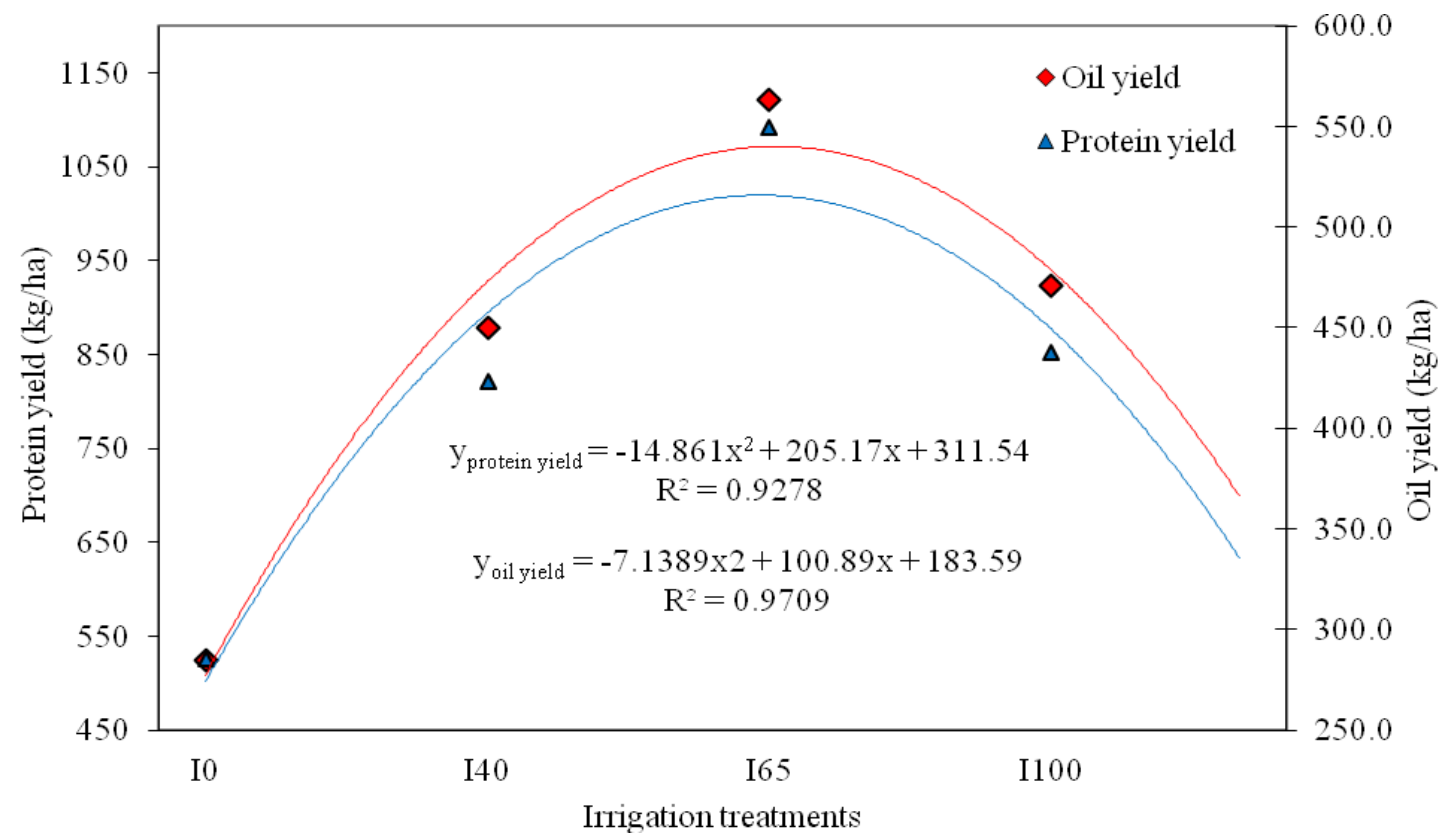

Figure 1. The relationship between amount of irrigation water - protein yield and oil yield 
Zn concentration in treatment $I_{65}$ was a much higher than in the rainfed and other irrigation treatments. Nonirrigated treatment and irrigation treatments $\mathrm{I}_{40}$ and $\mathrm{I}_{100}$ showed no notable differences in Zn concentrations of soybean.

Correlations between irrigation treatments, yields and quality parameters of soybean. The correlations between the irrigation treatments and the chemical characteristics of soybean, including yields, are shown in Table 2. Irrigation exhibited a strongly significant positive correlation with seed yields, oil yields, $\mathrm{K}$, $\mathrm{Mn}$ and $\mathrm{Cu}$, whereas the correlation with the protein content and $\mathrm{Ca}$ was strongly significant but negative. Irrigation exhibited a positive correlation with the oil content, but it was rather low $(r=0.15)$. Seed yields were in a strongly significant positive correlation with oil yields, protein yields, $\mathrm{K}, \mathrm{Mg}, \mathrm{Mn}$ and $\mathrm{Cu}$, whereas the correlation with the protein content and Ca was strongly significant but negative. A strongly significant negative correlation was established between $\mathrm{P}$ and $\mathrm{K}$ concentrations and protein content, and a strongly significant but positive correlation with Zn. P, K, and Zn exhibited a strongly significant negative correlation with Ca. However, a strongly significant positive correlation was established between $\mathrm{K}$ and $\mathrm{P}$. The correlation analysis revealed a negative correlation, albeit weak, between the protein content and oil content of soybean. A negative correlation between protein content and oil content was also reported by other researchers (e.g. Boydak et al., 2002).

Table 2. The correlations coefficients among yield and seed quality traits in soybean

\begin{tabular}{|c|c|c|c|c|c|c|c|c|c|c|c|c|c|c|}
\hline $\begin{array}{c}\text { Para- } \\
\text { meters }\end{array}$ & IT & SY & PC & PY & OC & OY & $\mathbf{P}$ & $\mathbf{K}$ & Ca & Mg & $\mathbf{F e}$ & Mn & $\mathbf{C u}$ & Zn \\
\hline $\mathrm{IT}^{\mathrm{a}}$ & 1 & $0.50^{b}$ & -0.58 & 0.47 & 0.15 & 0.56 & 0.27 & 0.51 & -0.60 & 0.37 & -0.08 & 0.63 & 0.60 & 0.05 \\
\hline SY & & 1 & -0.76 & 0.99 & -0.16 & 0.80 & 0.45 & 0.77 & -0.62 & 0.67 & -0.43 & 0.53 & 0.86 & 0.06 \\
\hline PC & & & 1 & -0.69 & -0.07 & -0.57 & -0.59 & -0.68 & 0.74 & -0.44 & 0.37 & -0.34 & -0.79 & -0.16 \\
\hline PY & & & & 1 & -0.20 & 0.80 & 0.41 & 0.76 & -0.58 & 0.68 & -0.44 & 0.54 & 0.84 & 0.07 \\
\hline OC & & & & & 1 & -0.29 & -0.06 & 0.01 & -0.31 & -0.22 & 0.21 & 0.01 & -0.01 & 0.40 \\
\hline OY & & & & & & 1 & 0.29 & 0.61 & -0.39 & 0.55 & -0.39 & 0.41 & 0.59 & -0.06 \\
\hline $\mathrm{P}$ & & & & & & & 1 & 0.79 & -0.65 & 0.33 & -0.18 & 0.18 & 0.61 & 0.52 \\
\hline $\mathrm{K}$ & & & & & & & & 1 & -0.74 & 0.58 & -0.31 & 0.48 & 0.86 & 0.54 \\
\hline $\mathrm{Ca}$ & & & & & & & & & 1 & -0.29 & 0.16 & -0.27 & -0.83 & -0.38 \\
\hline $\mathrm{Mg}$ & & & & & & & & & & 1 & -0.51 & 0.58 & 0.50 & -0.18 \\
\hline $\mathrm{Fe}$ & & & & & & & & & & & 1 & 0.01 & -0.29 & 0.18 \\
\hline $\mathrm{Mn}$ & & & & & & & & & & & & 1 & 0.55 & -0.03 \\
\hline $\mathrm{Cu}$ & & & & & & & & & & & & & 1 & 0.32 \\
\hline $\mathrm{Zn}$ & & & & & & & & & & & & & & 1 \\
\hline
\end{tabular}

${ }^{\mathbf{a}} \mathrm{IT}=$ Irrigation treatments, $\mathrm{SY}=$ seed yield, $\mathrm{PC}=$ protein content, $\mathrm{PY}=$ protein yield, $\mathrm{OC}=$ oil content, $\mathrm{OY}=$ oil yield.

${ }^{\mathbf{b}}$ Marked correlations are significant at $P<0.05$.

\section{DISCUSSION}

Our results showed that the yield and chemical composition of the tested soybean variety was affected by the water-save regimes. The soybean seed yield under full irrigation $\left(\mathrm{I}_{100}\right)$ was $5.49 \%$ and $65.03 \%$ higher than under $\mathrm{I}_{40}$ and $\mathrm{I}_{0}$, respectively, but $16.20 \%$ lower than that under treatment $\mathrm{I}_{65}$. A large number of factors, including reduced activity of Rhizobia and potential $\mathrm{O}_{2}$ stress during the period of soybean reproduction, could have contributed to lower yields under treatment $\mathrm{I}_{100}$, compared to $\mathrm{I}_{65}$. Al-Tawaha et al. (2007) have also observed that soybean yield is affected significantly when the amount of irrigation water increases. Variance analysis revealed statistically significant differences in the percent of protein content between the treatments. Foroud et al. (1993) reported significant effects of irrigation levels on seed protein. On the other hand, Al-Tawaha et al. (2007) established that irrigation levels had no effect on the protein content of soybean in Québec, Canada. The present research established a strong polynomial correlation between the soybean protein yield and the amount of water used during the growing season, which is consistent with Candogan et al. (2013).

In our experimental conditions, the oil content did not differ between irrigation treatments. Similarly to our results, Al-Tawaha et al. (2007) found that irrigation had no effect on the oil content, regardless of the amount of irrigation water applied. In contrast to our results, Kirnak et al. (2010) examined the effect of different drip irrigation rates on soybean yield and quality over two years under semi-arid conditions in Turkey (Harran Plain) and recorded the highest oil content of non-irrigated $\left(\mathrm{I}_{0}\right)$ soybean in both years. On the other hand, the same researchers 
established a much broader interval of oil content variation between the treatments they studied (15.30-17.96\% in 2003 and $16.40-20.10 \%$ in 2004).

According to Henry (2010), the optimal oil content and protein content of soybean are about $20 \%$ and $35 \%$, respectively, on average. In the present research the oil content, regardless of the treatment, varied around $20 \%$ and the protein content was greater than $35 \%$. With regard to the percent of oil and protein content, the results reported here are similar to those of Kirnak et al. (2010), who emphasized that water stress affects grain quality. The differences between the results of the present study and those reported by others can be attributed to different time, severity and duration of drought, metabolic state of the plant, stage of growth, applied agrotechnical measures or even the genotype or cultivar response to irrigation (Reddy et al, 2004; Bettaieb et al., 2011).

Statistical regression analysis revealed a significant $(P<0.05)$ polynomial correlation between the oil yield per hectare and the amount of irrigation water used during the growing season of soybean in temperate climate conditions in Srem (Figure 1). The results reported here differ from those of Candogan et al. (2013), given that they established that the oil yield of soybean increases linearly with increasing amounts of irrigation water under subhumid climate conditions in Turkey.

The macro- and micromineral content of soybean is a very important component of its chemical composition. The results of the present study demonstrate mainly the positive impact of irrigation on mineral composition of soybean seed. Reported results show that there have been no distinct trends between micromineral concentrations and the studied irrigation treatments. The content of macro- and microminerals depends to a large extent on environmental drivers (Zhang et al., 2010). Irrigation often leads to reduced concentrations of mineral elements in plant tissues (Loladze, 2002). According to White and Broadley (2009), much of recent research shows that the concentrations of various mineral elements are low in high-yielding genotypes.

Concentrations of macro- and microminerals in soybean constitute extremely important information for soybean processing industry, given that soybean is extensively used in human and animal nutrition. Calcium is an important mineral in human nutrition, especially for bone development and hardness (Shegro et al., 2012). Calcium deficiency is deemed to be a public health concern (WHO, 2004). Magnesium and copper deficiencies often cause health issues on a regional scale (White and Broadley, 2009).

Concentrations of microminerals, such as $\mathrm{Fe}, \mathrm{Mn}, \mathrm{Zn}$ and $\mathrm{Cu}$, are another important component of the chemical composition of soybean (Waters and Sankaran, 2011). Despite their nutritional value, high concentrations of certain microminerals, such as $\mathrm{Cu}$ and $\mathrm{Zn}$, can be toxic to both people and animals (Wang et al., 2008). In many countries of the world, especially developing countries, iron, zinc and copper are the three most often lacking micro-nutrients in human food (White and Broadley, 2005); this deficiency frequently causes health issues. Zinc plays an important role because it affects growth and development, as well as proper functioning of the human immune system (Shegro et al., 2012).

\section{CONCLUSIONS}

Irrigation treatment $I_{65}$ recorded the highest seed yields $(3.21 \mathrm{t} / \mathrm{ha})$, protein $(1092 \mathrm{~kg} / \mathrm{ha})$ and oil $(563 \mathrm{~kg} / \mathrm{ha})$ yields, followed by treatments $\mathrm{I}_{100}, \mathrm{I}_{40}$ and $\mathrm{I}_{0}$. Treatment $\mathrm{I}_{65}$ resulted in the highest protein content (39.2\%) of soybean, and treatment $\mathrm{I}_{100}$ measured the lowest protein content (36.5\%). The results also show that the irrigation treatments had a significant effect on the mineral content of soybean seeds and that they had no effect on the oil

content of soybean. However, the oil content exhibited less variation by the treatment than the protein content. The conclusion is that high seed and oil yields are achievable along with a high protein content of soybean in a wellwatered treatment (treatment $\mathrm{I}_{65}$ ) and that a larger amount of irrigation water (treatment $\mathrm{I}_{100}$ ) has no potential benefits. Although treatment $\mathrm{I}_{40}$ can result in a somewhat higher protein content and oil yield of soybean, compared to the rainfed treatment, seed yields might decrease significantly. Before farmers make use of this knowledge to produce high-quality soybean that meets the requirements of the nutrition market, it will be necessary to determine specific levels of soil moisture that will increase protein concentrations and the content of minerals essential for human health.

\section{ACKNOWLEDGEMENTS}

This study was supported by the Ministry of Education, Science and Technological Development of the Republic of Serbia (Contract Nos. III 43009 and TR 31037). 


\section{REFERENCES}

AL-TAWAHA A.M., SEGUIN P., SMITH D.L., BONNE R.B.: Irrigation level affects isoflavone concentrations of early maturing soya bean cultivars. J. Agron. Crop Sci., 193:238-246, 2007.

BETTAIEB I., KNIOUA S., HAMROUNI I., LIMAM F., MARZOUK B.: Water-deficit impact on fatty acid and essential oil composition and antioxidant activities of cumin (Cuminum cyminum L.) aerial parts. J. Agric. Food Chem., 59:328-334, 2011. BOYDAK E., ALPASLAN M., HAYTA M., GERCEK S., SIMSEK M.: Seed composition of soybeans grown in the Harran region of Turkey as affected by row spacing and irrigation. J. Agr. Food Chem., 50:4718-4720, 2002.

CANDOGAN B.N., SINCIK M., BUYUKCANGAZ H., DEMIRTAS C., GOKSOY A.T., YAZGAN S.: Yield, quality and crop water stress index relationships for deficit-irrigated soybean [Glycine max (L.) Merr.] in sub-humid climatic conditions. Agric. Water Manag., 118:113-121, 2013.

FOROUD, N., MÜNDEL, H.H., SAINDON, G., ENTZ, T.: Effect of level and timing of moisture stress on soybean yield, protein, and oil response. Field Crops Res., 31:195-209, 1993.

HENRY T.: The department of agriculture's (USDA) Grain Inspection, Packers \& Stockyards Administration (GIPSA) hand book: USDA soybean oil standards. Washington, USA, 2010.

KARAM F., MASAAD R., SFEIR T., MOUNZER O., ROUPHAEL Y.: Evapotranspiration and seed yield of field grown soybean under deficit irrigation conditions. Agric. Water Manag., 75:226-244, 2005.

KIM K.S., PARK S.H., KIM D.K., JENKS M.A.: Influence of water deficit on leaf cuticular waxes of soybean (Glycine max [L.] Merr.). Int. J. Plant Sci., 168:307-316, 2007.

KIRNAK H., DOGAN E., TURKOGLU H.: Effect of drip irrigation intensity on soybean seed yield and quality in the semi-arid Harran plain, Turkey. Span. J. Agric. Res., 8:1208-1217, 2010.

LIU F., ANDERSEN M.N., JENSEN C.R.: Loss of pod set caused by drought stress is associated with water status and ABA content of reproductive structures in soybean. Funct. Plant Biol., 30:271-280, 2003.

LIU K.S.: SOYBEANS: Chemistry, Technology, and Utilization. Chapman \& Hall, New York, pp. 442-466, 1997.

LIU X.B., HERBERT S.J., JIN J., ZHANG Q.Y., WANG G.H.: Responses of photosynthetic rates and yield/quality of main crops to irrigation and manure application in the black soil area of Northeast China. Plant Soil, 261:55-60, 2004.

Loladze I.: Rising atmospheric $\mathrm{CO}_{2}$ and human nutrition: toward globally imbalanced plant stoichiometry. Trends Ecol. Evol., 17:457-461, 2002.

REDDY A.R., CHAITANYA K.V., VIVEKANANDAN M.: Drought-induced responses of photosynthesis and antioxidant metabolism in higher plants. J. Plant Physiol., 161(16):1189-1202, 2004.

SHEGRO A., SHARGIE N.G., VAN BILJON A., LABUSCHAGNE M.T.: Diversity in starch, protein and mineral composition of sorghum landrace accessions from Ethiopia. J. Crop Sci. Biotech., 15(4):275-280, 2012.

STATISTICAL YEARBOOK OF THE REPUBLIC OF SERBIA, 2015. Available at: http://

http://webrzs.stat.gov.rs/WebSite/userFiles/file/Aktuelnosti/StatGod2015 (accessed January, 2017).

SWEENEY D.W., LONG J.H., KIRKHAM M.B.: A single irrigation to improve early maturing soybean yield and quality. Soil Sci. Soc. Am. J, 67:235-240, 2003.

WANG Z.H., LI S.X., MALHI S.S.: Effects of fertilization and other agronomic measures on nutritional quality of crops. J. Sci. Food Agric., 88:7-23, 2008.

WATERS B.M., SANKARAN R.P.: Moving micronutrients from the soil to the seeds: genes and physiological processes from a biofortification perspective. Plant Sci., 180:562-574, 2011.

WHITE P.J., BROADLEY M.R.: Biofortification of crops with seven mineral elements often lacking in human diets - iron, zinc, copper, calcium, magnesium, selenium and iodine. New Phytol., 182:49-84, 2009.

WHITE P.J., BROADLEY M.R.: Biofortifying crops with essential mineral elements. Trends Plant Sci., 10:586-593, 2005.

WHO. Vitamin and mineral requirements in human nutrition. World Health Organization. Geneva, 2004.

ZHANG Y., SONG Q., YAN J., TANG J., ZHAO R., ZHANG Y., HE Z., ZOU C., ORTIZ-MONASTERIO I.: Mineral element concentrations in grains of Chinese wheat cultivars. Euphytica, 174:303-313, 2010. 


\title{
UTICAJ REDUKOVANOG NAVODNJAVANJA NA PRINOS I HEMIJSKA SVOJSTVA ZRNA SOJE U UMERENIM KLIMATSKIM USLOVIMA
}

\author{
Branka KRESOVIĆ, Boško GAJIĆ, Angelina TAPANAROVA, Borivoj PEJIĆ, Goran DUGALIĆ, \\ Zorica SREDOJEVIĆ
}

Izvod: Cilj ovog istraživanja bio je da utvrdi uticaj različitih nivoa deficita vode $\left(\mathrm{I}_{100}\right.$ : puno navodnjavanje, $\mathrm{I}_{65}$ : 35\% deficita, $\mathrm{I}_{40}$ : 60\% deficita i $\mathrm{I}_{0}$ : bez navodnjavanja) na prinos i hemijski sastav soje [Glycine max (L.) Merr.] gajene u Sremu, Srbija. Deficit vode značajno je uticao na prinos i hemijski sastav zrna soje. Najmanji (1,63 t/ha) prinos zrna ostvaren je u tretmanu bez navodnjavanja $\left(\mathrm{I}_{0}\right)$, a najveći $(3,21 \mathrm{t} / \mathrm{ha})$ na tretmanu $\mathrm{I}_{65}$. Pored toga, najviši prinosi proteina (1092 kg/ha) i ulja (563 kg/ha) ostvareni su u tretmanu $\mathrm{I}_{65}$. Niži i viši nivoi navodnjavanja od $\mathrm{I}_{65}$ smanjili su prinose proteina i ulja. Naši podaci pokazuju da navodnjavanje uglavnom povećava sadržaj $\mathrm{K}, \mathrm{P}, \mathrm{Mg}$, $\mathrm{Mn}, \mathrm{Cu}, \mathrm{Zn}$ i B, a smanjuje sadržaj Ca i Fe u zrnu soje. Utvrđeno je da tretman punog zalivanja $\left(\mathrm{I}_{100}\right)$ ne predstavlja potencijalnu korist u smislu povećanja prinosa i poboljšanja hemijskog sastava zrna soje. Za postizanje visokih ekonomskih prinosa i dobrog hemijskog kvaliteta zrna, tretman $\mathrm{I}_{65}$ može biti pogodan za gajenje soje na području Srema kao i u drugim područjima sa sličnim zemljišnim i klimatskim uslovima.

Ključne reči: soja, stres suše, hranljive materije, prinosi proteina i ulja, sadržaj minerala

\author{
Received / Primljen: 04.11.2016.
} Accepted / Prihvaćen: 04.07.2017. 